\title{
Batch CGTase Production with Free and Immobilized Bacillus firmus Strain 37 in Bovine Bone Charcoal
}

\author{
Larissa Albunio Silva1 ${ }^{*}$, Graciette Matioli², Gisella Maria Zanin'1, Flavio Faria Moraes ${ }^{1}$ \\ ${ }^{1}$ Chemical Engineering Department, State University of Maringa, Maringá, Brazil \\ ${ }^{2}$ Pharmaceutical Sciences Department, State University of Maringa, Maringá, Brazil \\ Email: `larissa_albunio@yahoo.com.br, gmatioli@uem.br, gmzanin@uem.br, ffariamoraes@gmail.com
}

How to cite this paper: Silva, L.A., Matioli, G., Zanin, G.M. and Moraes, F.F. (2021) Batch CGTase Production with Free and Immobilized Bacillus firmus Strain 37 in Bovine Bone Charcoal. Advances in Chemical Engineering and Science, 11, 91-104. https://doi.org/10.4236/aces.2021.111007

Received: December 15, 2020

Accepted: January 25, 2021

Published: January 28, 2021

Copyright $\odot 2021$ by author(s) and Scientific Research Publishing Inc. This work is licensed under the Creative Commons Attribution International License (CC BY 4.0).

http://creativecommons.org/licenses/by/4.0/

\begin{abstract}
The present study aimed to study the batch production of CGTase (cyclomaltodextrin-glucanotransferase) with Bacillus firmus strain 37 free and immobilized in bovine bone charcoal in batch mode and in a fluidized bed batch reactor, respectively. The bovine bone charcoal is an innovative support material for the immobilization of microorganisms' producers of enzymes and the use of this microbial support allows its reuse to a significant cost reduction of the process. The batch fermentation with free cells was investigated for $96 \mathrm{~h}$ and reached a CGTase activity equal to $0.77 \mathrm{U} / \mathrm{mL}$. When the microorganism was immobilized on bovine bone charcoal $(7 \mathrm{~g})$ and cultivated in fluidized bed batch reactor with air supplementation ( 1 volume of air/volume of medium ${ }^{\star}$ minute), the same activity could be achieved in $24 \mathrm{~h}$. The results of enzymatic activity achieved show the potential of CGTase production in a short time with Bacillus firmus strain 37 immobilized in bovine bone charcoal matrix and using air supplementation in the production medium.
\end{abstract}

\section{Keywords}

Bacillus firmus, CGTase, Bone Charcoal Matrix, Fluidized Bed Batch Reactor, Cell Immobilization

\section{Introduction}

CGTase ( $\alpha$-1,4-glucan-4-glycosyltransferase) is a bacterial enzyme which has a molecular mass of around $70-78 \mathrm{kD}$ and whose amino acid sequence shows structural similarity to $\alpha$-amylase enzyme. CGTase consists of a single chain polypeptide of approximately 650 amino acids and depends on calcium to maintain its catalytic activity [1] [2] [3]. 
The CGTase is considered a multifunctional enzyme, which catalyzes four reactions, among which cyclization is considered the most important. This reaction produces cyclodextrins (CDs) from starch chains, which must have more than five glucopyranosyl residues and a helical shape [4] [5] [6]. In addition, CGTase industrial importance is also related to the production of other carbohydrates such as amylose, amylopectin and maltose oligosaccharides [7]. The three most common types of CGTases identified are $\alpha, \beta$ - and $\gamma$-CGTase as the predominance of the type of $\mathrm{CD}$ produced, i.e. CGTases produce mainly $\alpha$-CD, while $\beta$ - and $\gamma$-CGTase producing $\beta$ - and $\gamma$-CDs, respectively. However, the predominance of each $\mathrm{CD}$ depends on $\mathrm{pH}$, temperature, its microbial origin, i.e. the microorganism producing the enzyme and also the reaction time. In all cases, however, prolonged reaction times result in the formation of a mixture of all three types of $\mathrm{CDs}$ with $\beta$-CD representing the predominant reaction product [8] [9] [10].

CDs are capable of forming inclusion complexes with various organic and inorganic molecules [11], frequently increasing their stability. This stability can be manifested as volatility reduction, sublimation, heat resistance increase, hydrolysis resistance, oxidation resistance and increased solubility [1] [12] [13] [14].

CGTase is produced mainly by members of the genus Bacillus, especially by those aerobic and alkalophilic. Alkalophilic Bacillus, such as B. firmus strain 37, has attracted great interest due to its significant activity on high $\mathrm{pH}$ (above 9) and relatively high temperatures (often above $37^{\circ} \mathrm{C}$ ) [15] [16].

Starch is usually the substrate used in the production of CGTase. In the metabolism of CGTase microorganism producers, starch is converted to CD, producing energy. Starch can be produced from $\mathrm{CDs}$ under unfavorable conditions [17].

Besides that, most conventional industrial fermentation processes are carried using free cells in suspension, the use of immobilized microorganisms has been considered as an alternative to increase the overall yield of fermentations [18].

There are many materials that work as a support for microbial cells in CGTase production processes, such as stones, coal, polymers, alginates, membranes, among others. The choice of a suitable matrix is fundamental to obtain the desired product. The matrix must have a large surface area with interstitial space for cell growth; be easily regenerated and reusable; propitiate cell viability and catalytic activity for long periods; provide uniform porosity to allow mass transfer; have good mechanical, chemical, thermal and biological stability [19] [20]. In this search for the best support for immobilization of microorganisms in the production of enzymes, bovine bone charcoal characteristics and potential were evaluated in this work. This product has aroused great interest in immobilization of cells, due to its high porosity, which enables microorganisms' colonies and grows not only on the support surface, but inside it, increasing productivity due to higher cell concentration [21] [22].

In immobilized fermentations, fluidized bed reactors are an interesting op- 
tion. The main feature of this reactor is that the liquid velocity is greater than the sedimentation velocity of support particles, keeping them in suspension. This allows the support to retain high concentration of biomass, improving biomass-substrate contact and allowing operation at low residence times [23].

In this paper, the batch production of CGTase with Bacillus firmus strain 37 free and immobilized in bone charcoal was evaluated in batch and in a fluidized bed batch reactor, respectively. The effects of immobilization and aeration rate were also assessed and discussed.

\section{Materials and Methods}

\subsection{Microorganism and Culture Conditions}

Bacillus firmus strain 37 was isolated from the soil of manioc plantation and identified by Matioli [24]. For the reactivation, it was first grown at $37^{\circ} \mathrm{C}$ for 48 $\mathrm{h}$ on solid medium with the composition according to Nakamura, Horikoshi [25] and Matioli [24]. Single colonies were then transferred to a liquid medium with the same composition, except for agar, dye and starch (which was used in $2 \%(\mathrm{w} / \mathrm{v})$ concentration). The liquid culture was maintained in an incubator at $130 \mathrm{rpm}$ and $37^{\circ} \mathrm{C}$ for $24 \mathrm{~h}$.

\subsection{Preparation of Matrix and Immobilization}

Bovine bone charcoal samples were provided by the company "Bonechar Activated Charcoal from Brazil". Charcoal was sieved in particles of 0.83 and 0.58 $\mathrm{mm}$. This selection was carried out with the objective of standardizing the particles to ensure reproducibility and repeatability of the experiments with Bacillus firmus fixed in this support. For biomass immobilization the reactivated culture was added to a column containing sterile charcoal. After $24 \mathrm{~h}$ the immobilization medium was removed. To the column containing immobilized cell in charcoal it was added cell-free medium. The characterization of bovine bone charcoal, such as the physicochemical properties, was carried out by isotherms adsorption of $\mathrm{N} 2$ to estimate specific area through B.E.T. (Brunauer-Emmett-Teller) model and the results can be consulted in our published paper in 2018 [26].

\subsection{Fermentations}

For the fermentations with immobilized cells it was used $7 \mathrm{~g}$ of bone charcoal and aeration rate of $1 \mathrm{v} / \mathrm{v} / \mathrm{m}$ (volume of air/volume of medium ${ }^{*}$ minute). Immobilized fermentations were carried in a single batch $(168 \mathrm{~h})$ and in five sequential batch of $48 \mathrm{~h}$ each. Free cells fermentations were performed during 96 h.

\subsection{Analytical Methods}

\subsubsection{Protein Determination}

Protein concentration was measured by the method of Lowry [27] using bovine serum albumin as standard. 


\subsubsection{Determination of $\beta$-CD}

$\beta$-cyclodextrin ( $\beta$-CD) was quantified by the phenolphthalein (PHE) colorimetric method [28] [29].

The $\beta$-CD concentration was determined by Equation (1). ABS is the sample absorbance; $\mathrm{ABSo}$ is the absorbance of PHE in distilled water (auto-zero), $\beta$ - $\mathrm{CD}$ is the concentration of $\beta$-CD expressed in $\mathrm{mM}$; and $\mathrm{k}$ is the equilibrium constant of complex formation $\beta$-CD/PHE. $k$ value was determined by nonlinear regression, using a standard concentration of $\beta$-CD $\left((0-1) \times 10^{-3} \mathrm{M}\right)$ made up in distilled water; while a is the total concentration of the assay phenolphthalein $(5 \times$ $\left.10^{-5} \mathrm{M}\right)$ (Equation (2)).

$$
\begin{gathered}
C_{\beta-\mathrm{CD}}=a\left[1-\frac{\mathrm{ABS}}{\mathrm{ABS}_{o}}\right] \cdot\left[1+\frac{\mathrm{ABS}_{o}}{a \cdot k \cdot \mathrm{ABS}}\right] \\
C_{\beta-\mathrm{CD}}=0.3\left[1-\frac{\mathrm{ABS}}{\mathrm{ABS}_{o}}\right] \cdot\left[1+1.07215 \frac{\mathrm{ABS}_{o}}{\mathrm{ABS}}\right]
\end{gathered}
$$

The equilibrium constant $(k)$ was calculated using the Quasi-Newton method $\left(18655.7 \mathrm{M}^{-1}\right)$. Equation (1) was obtained by replacing the value of $k$ and the a value in the Equation (2) and multiplying this equation by a factor equal 6000 , which is related to the dilution procedure (converts $\mathrm{M}$ in $\mathrm{mM}$, the unit of concentration of $\beta-\mathrm{CD})$.

\subsubsection{CGTase Activity}

The enzyme activity is determined by the Initial Velocity Method according to Hamon and Moraes [30], under the following conditions: $50^{\circ} \mathrm{C}$ (activation of the enzyme), $\mathrm{pH} 8.0$ (greater enzyme stability) and low enzyme concentrations (0.4 $\mathrm{mM}$ ), so that the $\beta$-CD concentrations produced in time function have a linear relationship.

The substrate stock solution was made using $1 \%$ dextrin, dissolved in $50 \mathrm{~mL}$ of stock solution of $\mathrm{CaCl}_{2}(5 \mathrm{mM})$ and $100 \mathrm{~mL}$ of Tris- $\mathrm{HCl}$ buffer $(0.05 \mathrm{M}, \mathrm{pH}$ 8.0).

Data ( $\mu$ moles $\beta$-CD produced/culture $\mathrm{mL} / \mathrm{min}$ ) were plotted as a function of reaction time. The slope of the straight line $(K)$ was used to calculate the volumetric activity (Equation (3)).

$$
A=\left(K \cdot V_{R} \cdot D\right) / V_{E}
$$

where: $A=$ volumetric activity in $\mu$ moles $\beta-\mathrm{CD} /(\mathrm{min} \times \mathrm{mL}$ of enzyme solution), $K=$ slope of the concentration of CDs produced as a function of reaction time $\left((\mu\right.$ moles $\beta-\mathrm{CD} /(\mathrm{mL} \times \mathrm{min})), D=$ actual dilution of enzymatic means, $V_{R}=$ reaction volume in $\mathrm{mL}$, or the diluted enzyme volume present in a test tube, $V_{E}=$ total reaction volume in $\mathrm{mL}$. One unit $(\mathrm{U})$ of activity is considered as the enzyme amount that catalyzes the conversion of one $\mu \mathrm{mol}$ of substrate (or producing one $\mu \mathrm{mol}$ of product) per minute, in the reaction conditions ( $\mathrm{pH} 8$ and $\left.50^{\circ} \mathrm{C}\right)$. 


\section{Results and Discussion}

\subsection{Free Cell Fermentation}

Enzyme production in free cells batch without air supplementation were carried to determine the growth profile and to compare the CGTase activities to those achieved in fermentations carried with immobilized cells with air supplemented.

Figure 1 presents the results of CGTase activity $(\mathrm{U} / \mathrm{mL})$, biomass concentration $(\mathrm{g} / \mathrm{L})$ in batch mode fermentation without air supplementation during $96 \mathrm{~h}$.

CGTase activity and biomass concentration reached $0.77 \mathrm{U} / \mathrm{mL}$ and $1.28 \mathrm{~g} / \mathrm{L}$, respectively. These results were compared with the literature and are presented in Table 1.

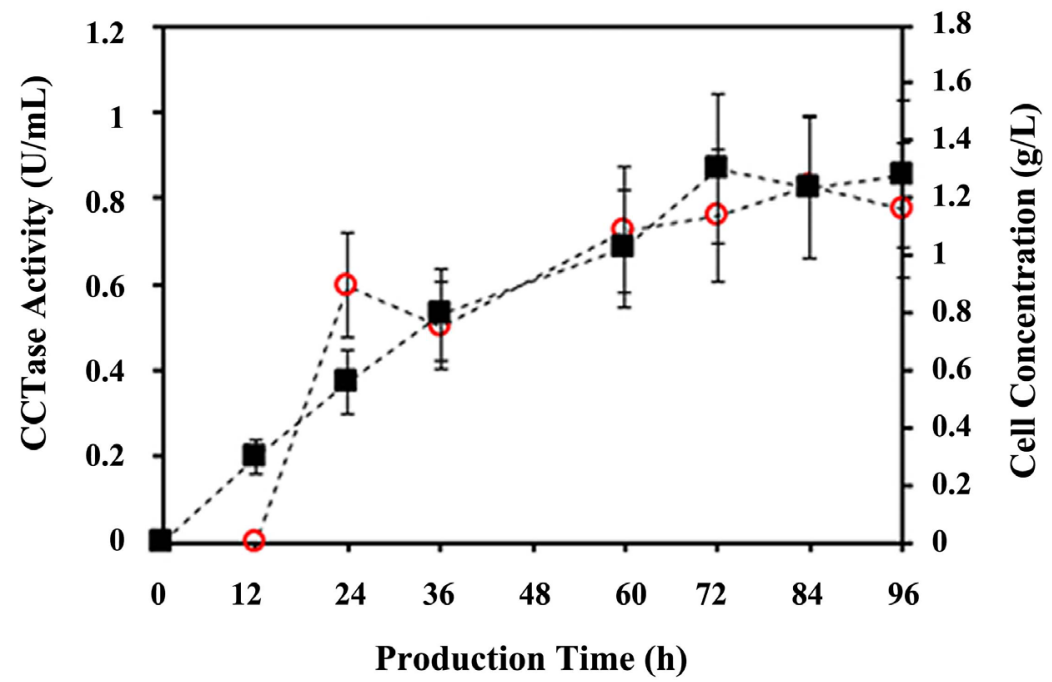

Figure 1. CGTase activity (circle) and cell concentration (square) versus time for enzyme production with free cells of Bacillus firmus strain 37 in the medium in shaker. Fermentation was carried in duplicate.

Table 1. Studies on CGTase production using free microorganism in the culture medium.

\begin{tabular}{cccc}
\hline Microorganisms & $\begin{array}{c}\text { Production Time } \\
\text { (h) }\end{array}$ & $\begin{array}{c}\text { CGTase activity } \\
\text { (U/mL) }\end{array}$ & References \\
\hline B. pseudalcaliphilus & 24 & 0.06 & {$[15]$} \\
B. lehensis & 72 & 134 & {$[16]$} \\
Bacillus G1 & 144 & 77 & {$[31]$} \\
B. sphaericus & 144 & 0.048 & {$[6]$} \\
Bacillus sp. 20RF & 48 & 0.22 & {$[32]$} \\
Bacillus sp. 8 SB & 12 & 0.12 & {$[33]$} \\
B. licheniformis & 48 & 0.162 & {$[34]$} \\
PaeniBacillus campinasensis & 30 & 134 & {$[35]$} \\
B. circulans & 18 & 0.12 & {$[36]$} \\
B. alcalophilic CGII & 120 & 88.6 & {$[37]$} \\
B. firmus strain 37 & & 0.55 & \\
\hline
\end{tabular}

$\mathrm{U}=\mu$ moles $\beta-\mathrm{CD} /(\mathrm{mL} \times \mathrm{min})$. 
According to Table 1, Alves and colleagues [37] reported a CGTase activity very close to the one achieved in this work $(0.55 \mathrm{U} / \mathrm{mL})$ using the same microorganism (B. firmus strain 37), however in our work this same value was reached after 36 hours of fermentation, while they took 120 hours. Moreover, Alves [37] used hydrolyzed starch as substrate and also higher amounts (four times higher) of yeast extract and peptone.

It was also noticed a direct relationship between the CGTase activity and biomass concentration of $B$. firmus strain 37. It means that the same culture conditions that promotes biomass growth, also favored enzyme production. It was reported by Gawande [38] and Pinto [39], where maximal CGTase activity was achieved at the end of the exponential phase. Vassileva and coauthors [40] worked with different aeration conditions and found a similar profile using $\mathrm{Ba}$ cillus circulans. By contrast, other authors such as Rosso [41] and Moriwaki [6] documented that high concentrations of biomass contribute to a more viscous reaction medium, resulting in reduced dissolved oxygen and consequently lower enzyme activity. In this work cell concentration in the medium (Figure 1) did not result in loss of oxygen transfer, which can be explained by the mechanical agitation of the medium.

It was also noticed in Figure 1 that the duration of the exponential growth phase was $72 \mathrm{~h}$, in which the cell division and reproduction is extremely active and with higher metabolic activity. Another is the stationary phase between $72 \mathrm{~h}$ and $96 \mathrm{~h}$, this period decreases cell growth and the microbial population is stable, since the number of cell death is equivalent to the number of new cells, also occurring accumulation of metabolites such as enzymes [42]. It was not possible to identify the phase lag (phase microbial adaptation) and cell death or decline because the lag phase may have occurred in the first hours, or before $12 \mathrm{~h}$, the cell concentration was not measured, and phase of cell death occurred after $96 \mathrm{~h}$. It was important to identify the phases of cell growth, since the results will be considered in the immobilization of the microorganism in bone coal, that is, cell immobilization should be made in the period in which $B$. firmus strain 37 is in its best phase reproduction. This phase is log phase or microbial growth (between 12 and $72 \mathrm{~h}$ ) as there are more viable cells in the production medium.

\subsection{Immobilized Cell Single Batch Fermentation}

The interaction between the charcoal and immobilized microorganisms was studied in our article published in 2018 [26], in which it was possible to observe by SEM microscopy (Scanning electron microscopy) the adhered rod-shaped microorganisms, probably Bacillus firmus, in the activated bone charcoal, proving the success of cell immobilization. Immobilized cell fermentation was carried in order to determine the enzyme activity profile during time. A single batch fermentation was then carried with total duration of $168 \mathrm{~h}$ using air supplementation of $1 \mathrm{v} / \mathrm{v} / \mathrm{m}$. The results of CGTase activities are shown in Figure 2.

In Figure 2, it was observed that CGTase enzyme activity rapidly increased with time until $48 \mathrm{~h}$, maintaining relatively constant to $84 \mathrm{~h}$. The higher CGTase 


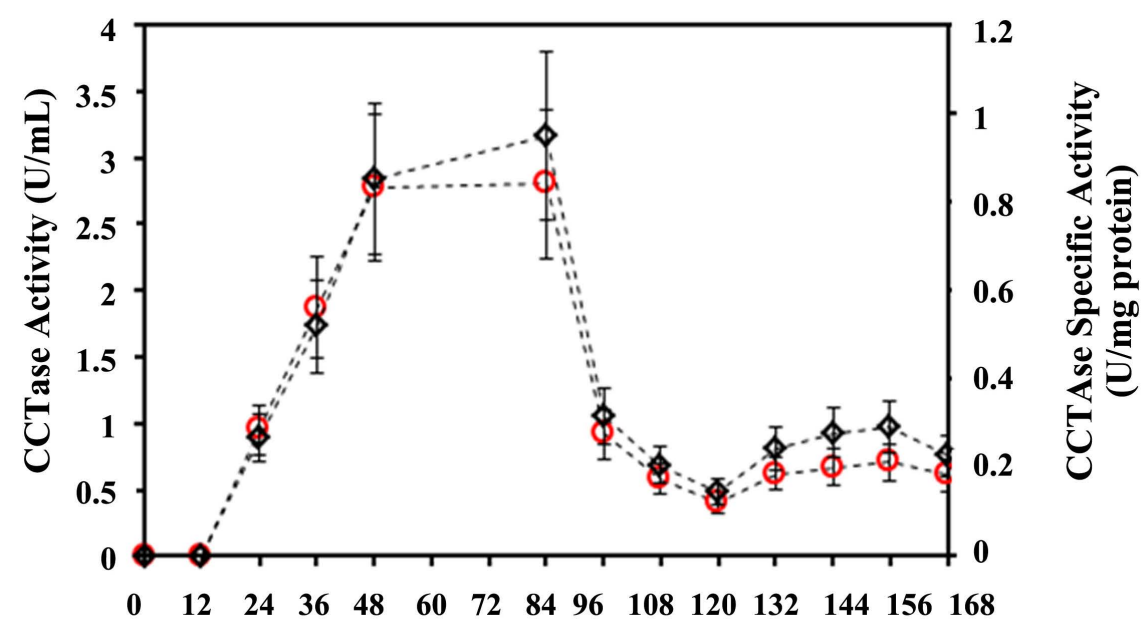

Production Time (h)

Figure 2. CGTase activity (circle) and specific activity of CGTase (diamond) against time enzyme production with Bacillus firmus strain 37 immobilized on bone charcoal.

activity was observed at $84 \mathrm{~h}(2.8 \mathrm{U} / \mathrm{mL})$ but was very close to the one at $48 \mathrm{~h}$ $(2.7 \mathrm{U} / \mathrm{mL})$. After $84 \mathrm{~h}$ a rapid decrease in enzyme activity was observed, which has undergone partial recovery after $120 \mathrm{~h}$. At the end of the fermentation (168 h) of the CGTase activity was $0.6 \mathrm{U} / \mathrm{mL}$. Vassileva and co-authors [43] worked with Bacillus circulans immobilized in agar in non-aerated batch mode and achieved a CGTase activity of approximately $0.15 \mathrm{U} / \mathrm{mL}$ after $72 \mathrm{~h}$ of fermentation, much lower when compared to the results achieved in this study $(3 \mathrm{U} / \mathrm{mL})$. This indicates that aeration is a very important parameter in CGTase production.

The concentration of total reducing sugars and the $\mathrm{pH}$ values were determined and monitored during the fermentation and are shown in Figure 3.

In respect to the reducing sugar concentration, it can be observed a decrease over time, especially during the first $12 \mathrm{~h}$ (reaching $9 \mathrm{~g} / \mathrm{L}$ ). Total reducing sugars was reduced close to zero after $168 \mathrm{~h}$. In relation to the $\mathrm{pH}$, it ranged from 11 (initial $\mathrm{pH}$ ) to $9.3(168 \mathrm{~h}$ ), which is ideal $\mathrm{pH}$ for $B$. firmus growth and CGTase production [44]. The observed low decrease in $\mathrm{pH}$ is also interesting because since enzymes are proteins, the ionic characters of the amino and carboxylic groups are affected by changes in $\mathrm{pH}$. According to Matioli [24], enzyme breakdown at very high $(>11)$ or low $(<8) \mathrm{pH}$ compromises the efficient production of the CGTase, resulting in lower enzyme activity values.

\subsection{Immobilized Cell Sequential Batch Fermentations}

In order to decrease fermentation time and improve CGTase activity immobilized cell sequential fermentations were performed. The objective was to understand and identify those parameters that influence positively or negatively enzyme activity, such as agitation, aeration, minimum flow, $\mathrm{pH}$, etc.

First the bone charcoal was characterized and its specific surface area was 


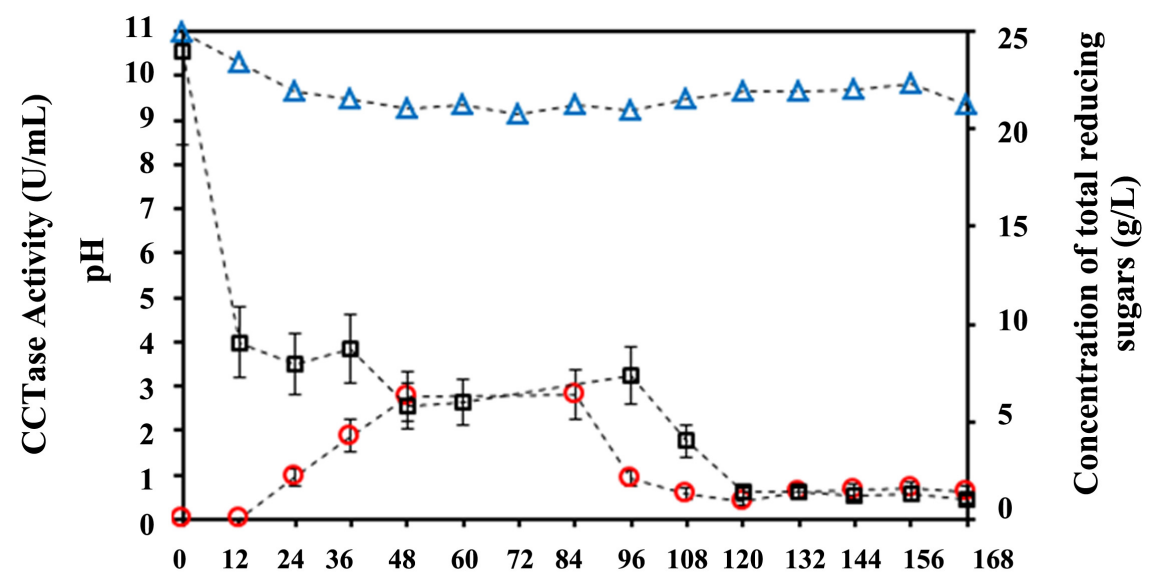

Production Time (h)

Figure 3. CGTase activity (circle), pH (triangle) and total reducing sugars concentration (square) versus time for enzyme production with immobilized Bacillus firmus strain 37 on bone charcoal.

found to be $123.5 \mathrm{~m}^{2} / \mathrm{g}$, while the total pore volume was equal to $0.277 \mathrm{~cm}^{3} / \mathrm{g}$ and the average pore diameter was $89.85 \AA$, defined as micropores. These data were estimated using the B.E.T. (Brunauer-Emmett-Teller) model [45].

Figure 4 shows the results of CGTase activity and specific CGTase activity. It was noticed a progressive increase in enzyme activity, especially after the second batch, reaching a maximum of $3 \mathrm{U} / \mathrm{mL}$. Letsididi [46] studied the high $\mathrm{pH}$ tolerant Bacillus licheniformis for $\beta$-CGTase production in batch free cells fermentations with and without air supplementation and found that the maximum activity achieved was $0.14 \mathrm{U} / \mathrm{mL}$ in $48 \mathrm{~h}$. When compared with the results obtained in this study (Figure 4), the activities of CGTase we achieved were always higher, since the first batch.

Abdel-Naby [7] [47], Vassileva [43] and Atanasova [48] concluded, in their studies, that even if the microorganism requires cell adaptation to the environment it was possible to increase CGTase production in sequential batches, a result that is in accord with the results of this work.

Comparing the values of enzyme activity with free and immobilized cells, it was found that with the process carried with immobilized B. firmus strain 37 in repeated batches (Figure 4 ) (1st and $2 \mathrm{nd}=1.10 \mathrm{U} / \mathrm{mL} ; 3 \mathrm{rd}=1.56 \mathrm{U} / \mathrm{mL} ; 4$ th $=$ $2.8 \mathrm{U} / \mathrm{mL}$ and 5 th $=3.0 \mathrm{U} / \mathrm{mL}$ ) are much higher than the activity obtained in the assay with free $B$. firmus strain 37 without air supplementation $(0.6 \mathrm{U} / \mathrm{mL}$ in 48 $\mathrm{h}$ and $0.77 \mathrm{U} / \mathrm{mL}$ for $96 \mathrm{~h}$ ) (Figure 1). These results demonstrate that aeration (1 $\mathrm{v} / \mathrm{v} / \mathrm{m}$ ), cell immobilization and stirring are indicated in CGTase production processes.

Very different CGTase activities are described in the literature. Kuo and co-authors [49] achieved $13 \mathrm{U} / \mathrm{mL}$ in $15 \mathrm{~h}$ batch fermentation using Bacillus sp. in medium without air supplementation. Moriwaki [6] used Bacillus sphaericus strain 41 in non-immobilized batch and achieved a maximum activity of only 


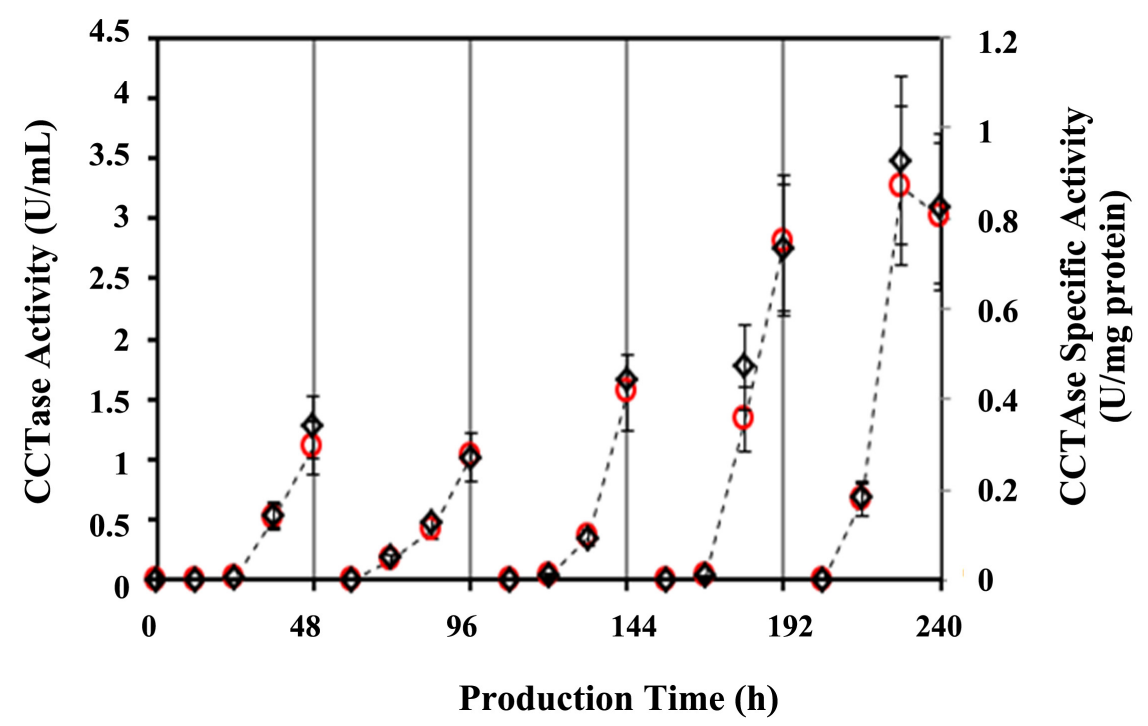

Figure 4. CGTase activity (circle) and specific activity (diamond) plotted against time in $48 \mathrm{~h}$ five sequential batches of Bacillus firmus strain 37 immobilized on bone charcoal.

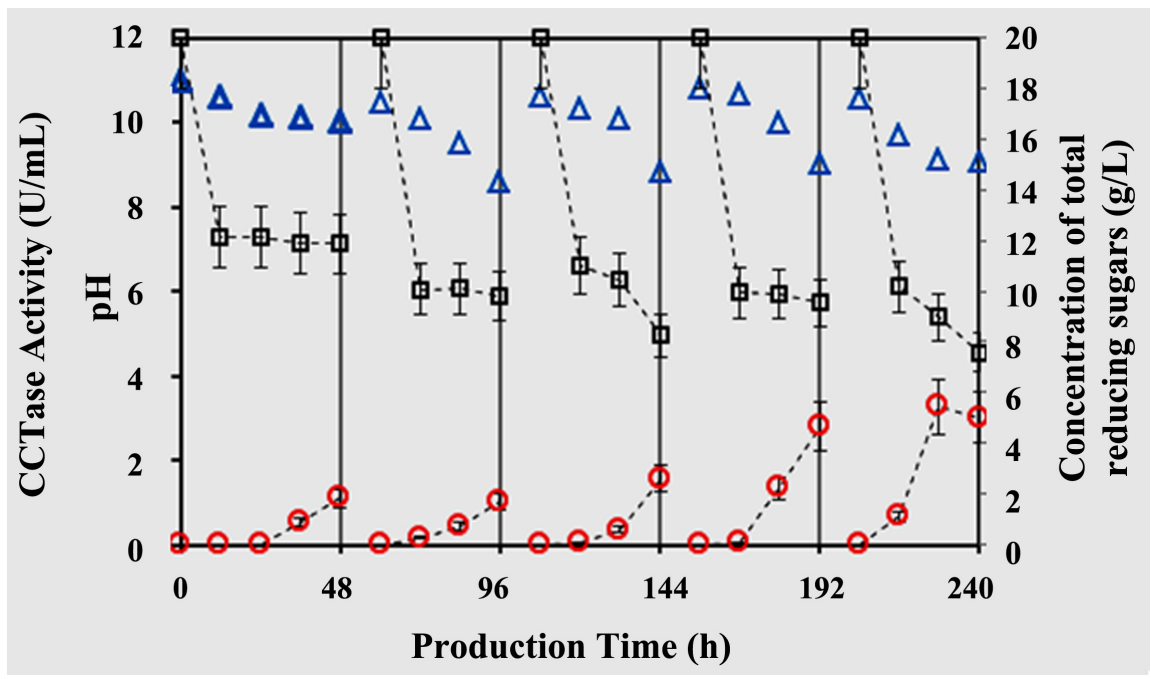

Figure 5. CGTase activity (circle), pH (triangle) and concentration of total reducing sugars (square) versus time for enzyme production with Bacillus firmus strain 37 immobilized on bone charcoal in five repeated batches of $48 \mathrm{~h}$ intervals.

$0.048 \mathrm{U} / \mathrm{mL}$ in $120 \mathrm{~h}$. These indicate that there are several factors besides the microorganism that can interfere with enzyme production, such as the source of starch (hydrolyzed or not), immobilization techniques, the support for microbial immobilization and aeration of the medium.

During sequential batch fermentations $\mathrm{pH}$ variation and the total reducing sugars during fermentation were also evaluated. They were correlated with the CGTase activity (Figure 5).

The $\mathrm{pH}$ variation was clearly dependent on the degradation of the carbon source (sodium carbonate). Final $\mathrm{pH}$ of the batches was never below 8.8, which is very close to the ideal $\mathrm{pH}$ for $B$. firmus strain 37 ( $\geq 9)$. It was also noticed from 
Figure 5 that the concentration of total reducing sugars decreases with time, as sugars, starches used in the medium are consumed by microorganisms through their metabolism. Enzyme production was not linked to carbon consumption, since the increase in CGTase activity was noticed after a rapid carbon uptake. This indicates that CGTase production is not directly associated to biomass production, in repeated batches with $B$. firmus strain 37 immobilized on bone charcoal.

\section{Conclusions}

In this work, it was possible to determine conditions leading to a high production of CGTase in batch with free and immobilized Bacillus firmus strain 37 in bovine bone charcoal. Enzyme production in free cells batch without air supplementation was $0.77 \mathrm{U} / \mathrm{mL}$ in $96 \mathrm{~h}$. In addition, it was noticed a direct relationship between the CGTase activity and biomass concentration of Bacillus firmus strain 37.

When Bacillus firmus strain 37 was immobilized on bovine bone charcoal particles, the enzyme production in a single batch of $84 \mathrm{~h}$ reached the same CGTase activity $(3 \mathrm{U} / \mathrm{mL})$ than the use of four sequential batches of $48 \mathrm{~h}$ (totalizing $192 \mathrm{~h}$ ). In addition, we observed that the CGTase production is not directly associated with biomass production in repeated batches with Bacillus firmus strain 37 immobilized on bone charcoal. These results demonstrate that aeration, cell immobilization, proper choice of immobilization matrix and the type of reactor used are important features in the CGTase production processes. Moreover, our results showed that a proper combination of that features allows to obtain high concentrations of the enzyme, and this, along with the reuse of the microbial support, conducts to a significant cost reduction of the process.

\section{Acknowledgements}

The authors thank the Coordination of Improvement of Higher Education Personnel (CAPES) for the financial support.

\section{Conflicts of Interest}

The authors have no conflicts of interest to declare.

\section{References}

[1] Cucolo, G.R., Alves-Prado, H.F., Gomes, E. and Silva, R. (2006) Optimisation of the Production of CGTase from Bacillus sp Subgroup Alcalophilus E16 by the Submerged Fermentation of Cassava Starch. Brazilian Journal of Food Technology, 9, 201-208.

[2] Matioli, G., Moriwaki, C., Mazzoni, R.B., Zanin, G.M. and Moraes, F.F. (2000) Study of Parameters That Influence the Production of the Enzyme CGTase from Bacillus firmus, Strain No. 37. Acta Scientiarum-Biological Sciences, 22, 311-316.

[3] Moriwaki, C., Pelissari, F.M., Gonçalves, R.A.C., Gonçalves, J.E., Matioli, G. (2007) Immobilization of Bacillus firmus Strain 37 in Inorganic Matrix for Cyclodextrin 
Production. Journal of Molecular Catalysis B: Enzymatic, 49, 1-7. https://doi.org/10.1016/j.molcatb.2007.07.003

[4] Bender, H. (1986) Production, Characterization and Application of CDs. Advances in Biotechnological Processes, 6, 31-71.

[5] Matioli, G., Zanin, G.M. and Moares, F.F. (2002) Influence of Substrate and Product Concentrations on the Production of Cyclodextrins by CGTase of Bacillus firmus, Strain no 37. Applied Biochemistry and Biotechnology, 98, 947-961. https://doi.org/10.1385/ABAB:98-100:1-9:947

[6] Moriwaki, C., Ferreira, L.R., Rodella, L.R.T. and Matioli, G. (2009) A Novel Cyclodextrin Glycosyltransferase from Bacillus sphaericus Strain 41: Production, Characterization and Catalytic Properties. Biochemical Engineering Jorunal, 48, 124-131. https://doi.org/10.1016/j.bej.2009.09.001

[7] Abdel-Naby, M.A. and El-Refai, Abdel-Fattah. (2011) Biosynthesis of Cyclodextrin Glucosyltransferase by the Free and Immobilized Cells of Bacillus Cereus NRC7 in Batch and Continuous Cultures. Journal Applied Microbiology, 111, 1129-1137. https://doi.org/10.1111/j.1365-2672.2011.05136.x

[8] Martins, R.F., Delgado, O. and Hatti-Kaul, R. (2003) Sequence Analysis of Cyclodextrin Glycosyltransferase from the Alkaliphilic Bacillus agaradhaerens. Biotechnology Letters, 25, 1555-1562.

[9] Mazzer, C., Ferreira, L.R., Rodella, J.R.T., Moriwaki, C. and Matioli, G. (2008) Cyclodextrin Production by Bacillus firmus Strain 37 Immobilized on Inorganic Matrices and Alginate Gel. Biochemical Enginerring Jorunal, 41, 79-86.

https://doi.org/10.1016/j.bej.2008.03.010

[10] Szejtli, J. (1988) Cyclodextrin Technology. Springer, Dordrecht. https://doi.org/10.1007/978-94-015-7797-7

[11] Bekers, O., Uijtendaal, E.V., Beijnen, J.H., Bult, A. and Underberg, W.J.M. (1991) Cyclodextrins in the Pharmaceutical Field. Drug Development and Industrial Pharmacy, 17, 1503-1549. https://doi.org/10.3109/03639049109026630

[12] Barão, C.E., Paiva-Martins, F., Zanin, G.M. and Moraes, F.F. (2013) Determination of the Inclusion Complex Constant between Oleuropein and Cyclodextrins by Complexation Theory. Journal of Inclusion Phenomena and Macrocyclic Chemistry, 78, 465-470. https://doi.org/10.1007/s10847-013-0318-x

[13] Bergamasco, R.C., Zanin, G.M. and Moraes, F.F. (2005) Sulfluramid Volatility Reduction by Beta-Cyclodextrin. Journal of Agricultural and Food Chemistry, 53, 1139. https://doi.org/10.1021/jf0486747

[14] Del Valle, E.M.M. (2004) Cyclodextrins and Their Uses: A Review. Process Biochemistry, 39, 1033-1046. https://doi.org/10.1016/S0032-9592(03)00258-9

[15] Atanasova, N., Kitayska, T., Bojadjieva, I., Yankov, D. and Tonkova, A. (2011) A Novel Cyclodextrin Glucanotransferase from Alkaliphilic Bacillus pseudalcaliphilus 20RF: Purification and Properties. Process Biochemistry, 46, 116-122. https://doi.org/10.1016/j.procbio.2010.07.027

[16] Blanco, K., Lima, C.J.B., Monti, R., Martins Jr., J., Bernardi, N.S. and Contiero, J. (2012) Bacillus Lehensis-An Alkali-Tolerant Bacterium Isolated from Cassava Starch Wastewater: Optimization of Parameters for Cyclodextrin Glucanotransferase Production. Annals of Microbiology, 62, 329-337. https://doi.org/10.1007/s13213-011-0266-X

[17] Wang, F., Du, G.C., Li, Y. and Chen, J. (2006) Regulation of CCR in the Gama-CGTase Production from Bacillus macorous by the Specific Cell Growth Rate Control. Enzyme and Microbial Technology, 39, 1279-1285. 
https://doi.org/10.1016/j.enzmictec.2006.03.014

[18] Ramakrishna, S.V. and Prakasham, R.S. (1999) Microbial Fermentations with Immobilized Cells. Current Science, 77, 87-100.

[19] Covizzi, L.G., Giese, E.C., Gomes, E., Dekker, R.F.H. and Silva, R. (2007) Immobilization of Microbial Cells and Their Biotechnological Applications. Semina: Exact Technology Science, 28, 143-160. http://dx.doi.org/10.5433/1679-0375.2007v28n2p143

[20] Liu, Y.K., Seki, M., Tanaka, H., Furusaki, S. (1998) Characteristics of Loofa (Luffa cylindrica) Sponge as a Carrier for Plant Cell Immobilization. Journal of Fermentation Bioengineering, 85, 416-421. https://doi.org/10.1016/S0922-338X(98)80086-X

[21] Postma, J., Nijhuis, E.H. and Someus, E. (2010) Selection of Phosphorus Solubilizing Bacteria with Biocontrol Potential for Growth in Phosphorus Rich Animal Bone Charcoal. Applied Soil Ecology, 46, 464-469. https://doi.org/10.1016/j.apsoil.2010.08.016

[22] Ngandwe, N. (2007) Toxicity of Animal Bone Charcoal from Pig and Cattle to Aquatic Bioassays: Vibrio fischeri, Daphnia Magna and Selenastrum capricornutum. Ph.D. Dissertation, Leipzig University, Leipzig.

[23] Correia, G.T. (2010) Effect of the Concentration of the Supporting Media and Relation between Areas on the Performance of Aerobic Fluidized Bed Reactors with Internal Circulation in the Treatment of Domestic Sewage. Ph. D. Dissertation. University Paulista State, Ilha Solteira.

https://repositorio.unesp.br/handle/11449/98075

[24] Matioli, G., Zazin, G.M., Guimarães, M.F. and Moraes, F.F. (1998) Production and Purification of CGTase of Alkalophylic Bacillus Isolated from Brazilian Soil. Applied Biochemistry and Biotechnology, 70, Article No. 267.

https://doi.org/10.1007/BF02920143

[25] Nakamura, N. and Horikoshi, K. (1976) Characterization and some cultural conditions of a cyclodextrin glycosyltransferase-producing alkalophilic Bacillus sp. Agricultural and Biological Chemistry, 40, 753-757. https://doi.org/10.1080/00021369.1976.10862122

[26] Silva, L., Bieli, B., Junior, O., Matioli, G., Zanin, G. and Moraes, F. (2018) Bovine Bone Charcoal as Support Material for Immobilization of Bacillus firmus Strain 37 and Production of Cyclomaltodextrin Glucanotransferase by Batch Fermentation in a Fluidized Bed. Advances in Chemical Engineering and Science, 8, 11-25.

[27] Lowry, O.H., Rosebrough, N.J., Farr, A.L. and Randall, R.J. (1951) Protein Measurement with the Folin Phenol Reagent. Journal of Biological Chemistry, 193, 265-275. https://doi.org/10.1016/S0021-9258(19)52451-6

[28] Tardioli, P.W., Zanin, G.M. and Moraes, F.F. (2000) Production of Cyclodextrins in a Fluidized-Bed Reactor Using Cyclodextrin-Glycosyl-Transferase. Applied Biochemistry and Biotechnology, 84, 1003-1019. https://doi.org/10.1385/ABAB:84-86:1-9:1003

[29] Tardioli, P.W., Zazin, G.M. and Morares, F.F. (2006) Characterization of Thermoanaerobacter Cyclomaltodextrin Glucanotransferase Immobilized on Glyoxil-Agarose. Enzyme and Microbial Technology, 39, 1270-1278.

https://doi.org/10.1016/j.enzmictec.2006.03.011

[30] Hamom, V. and Moraes, F.F. (1990) Etude Preliminare a L'Immobilisation de L'Enzime CGTase WACKER. Research Report, Laboratoire de Technologie Enzymatique. Université de Technologie de Compiègne, Compiègne.

[31] Ibrahim, H.M., Yusoff, W.M.W., Hamid, A.A. and Omar, O. (2010) Enhancement 
of Cyclodextrin Glucanotransferase Production by Bacillus G1 Using Different Fermentation Modes. Biotechnology, 9, 506-512.

https://dx.doi.org/10.3923/biotech.2010.506.512

[32] Atanasova, N., Petrova, P., Ivanova, V., Yankov, D., Vassileva, A. and Tonkova, A. (2008) Isolation of Novel alkaliphilic Bacillus Strains for Cyclodextrin Glucanotransferase Production. Applied Biochemistry and Biotechnology, 149, 155-167. https://doi.org/10.1007/s12010-007-8128-5

[33] Bonilha, P.R.M., Menocci, V., Goularti, A.J., de Moraes Polizeli, M., de L.T. and Monti, R. (2006) Cyclodextrin Glycosyltransferase from Bacillus Licheniformis: Optimization of Production and Its Properties. Brazilian Journal of Microbiology, 37, 317-323.

[34] Alves-Prado, H.F., Gomes, E. and da Silva, R. (2006) Evaluation of Solid and Submerged Fermentations for the Production of Cyclodextrin Glycosyltransferase by Paeni Bacillus Campinasensis H69-3 and Characterization of Crude Enzyme. In: McMillan, J.D., Adney, W.S., Mielenz, J.R. and Thomas Klasson, K., Eds., Twenty-Seventh Symposium on Biotechnology for Fuels and Chemicals, Humana Press, Totow, 234-246. https://doi.org/10.1007/978-1-59745-268-7 18

[35] Burhan, N., Sapundzhiev, T. and Beschkov, V. (2005) Mathematical Modelling of Cyclodextrin-Glucanotransferase Production by Batch Cultivation. Biochemical Engineering Journal, 24, 73-77. https://doi.org/10.1016/j.bej.2005.02.007

[36] de Freitas, T.L., Monti, R. and Contiero, J. (2004) Production of CGTase by a Bacillus Alkalophilic CGII Strain Isolated from Wastewater of a Manioc Flour Industry. Brazilian Journal of Microbiology, 35, 255-260. https://doi.org/10.1590/S1517-83822004000200015

[37] Alves, L.B., Matioli, G., De Moraes, F.F., Zanin, G.M. and Olivo, J.E. (2002) Production of the Enzyme Cyclodextringlycosyltransferase from Bacillus firmus alkalophilic. Journal of Inclusion Phenomena and Macrocyclic Chemistry, 44, 399-402. https://doi.org/10.1023/A:1023059601377

[38] Gawande, B.N., Singh, R.K., Chauhan, A.K., Goel, A. and Patkar, A.Y. (1998) Optimization of Cyclomaltodextrin Glucanotransferase Production from Bacillus firmus. Enzyme and Microbial Technology, 22, 288-291.

https://doi.org/10.1016/S0141-0229(97)00184-1

[39] Pinto, F.S.T., Flôres, S.H., Schneider, C.E., Ayub, M.A.Z. and Hertz, P.F. (2011) The Influence of Oxygen Volumetric Mass Transfer Rates on Cyclodextrin Glycosyltransferase Production by Alkaliphilic Bacillus Circulans in Batch and Fed-Batch Cultivations. Food and Bioprocess Technology, 4, 559-565.

https://doi.org/10.1007/s11947-009-0188-9

[40] Vassileva, A., Beschkov, V., Ivanova, V. and Tonkova, A. (2005) Continuous Cyclodextrin Glucanotransferase Production by Free and Immobilized Cells of Bacillus circulans ATCC 21783 in Bioreactors. Process Biochemistry, 40, 3290-3295.

https://doi.org/10.1016/j.procbio.2005.03.022

[41] Rosso, A.M., Ferrarotti, S.A., Krymkiewicz, N. and Nudel, B.C. (2002) Optimisation of Batch Culture Conditions for Cyclodextrin Glucanotransferase Production from Bacillus circulans DF 9R. Microbial Cell Factories, 1, Article No. 3.

https://doi.org/10.1186/1475-2859-1-3

[42] Borzani, W., Lima, U. de A. and Schmidell, W. (2001) Biotecnologia Industrial: Engenharia Bioquímica. Blucher, São Paulo, 197-216.

[43] Vassileva, A., Burhan, N., Beschkov, V., Spasova, D., Radoevska, S., Ivanova, V. and Tonkova, A. (2003) Cyclodextrin Glucanotransferase Production by Free and Agar 
Gel Immobilized Cells of Bacillus circulans ATCC 21783. Process Biochemistry, 38, 1585-1591. https://doi.org/10.1016/S0032-9592(03)00060-8

[44] Dixon, M., Webb, E., Dixon, M., Thorne, J.R. and Tipton, K.F. (1979) Enzymes. 3nd Edition, Longman Group Ltd., London.

[45] Gelb, L.D. and Gubbins, K.E. (1998) Characterization of Porous Glasses: Simulation Models, Adsorption Isotherms, and the Brunauer-Emmett-Teller Analysis Method. Langmuir, 14, 2097-2111. https://doi.org/10.1021/la9710379

[46] Letsididi, R., Sun, T., Mu, W., Kessy, N.H., Djakpo, O. and Jiang, B. (2011) Production of a Thermoactive Beta-Cyclodextrin Glycosyltransferase with a High Starch Hydrolytic Activity from an Alkalitolerant Bacillus licheniformis Strain Sk 13.002. Asian Journal of Biotechnology, 3, 214-225. https://dx.doi.org/10.3923/ajbkr.2011.214.225

[47] Abdel-Naby, M.A., Reyad, R.M. and Abdel-Fattah, A.F. (2000) Biosynthesis of Cyclodextrin Glucosyltransferase by Immobilized Bacillus amyloliquefaciens in Batch and Continuous Cultures. Biochemical Engineering Journal, 5, 1-9. https://doi.org/10.1016/S1369-703X(99)00030-3

[48] Atanasova, N., Kitayska, T., Yankov, D., Safarikova, M. and Tonkova, A. (2009) Cyclodextrin Glucanotransferase Production by Cell Biocatalysts of Alkaliphilic Bacilli. Biochemical Engineering Journal, 46, 278-285. https://doi.org/10.1016/j.bej.2009.05.020

[49] Kuo, C.C., Lin, C.A., Chen, J.Y., Lin, M.T. and Duan, K.J. (2009) Production of Cyclodextrin Glucanotransferase from an Alkalophilic Bacillus sp. by $\mathrm{pH}-\mathrm{Stat}$ Fed-Batch Fermentation. Biotechnology Letters, 31, Article No.1723.

https://doi.org/10.1007/s10529-009-0071-9 